\title{
Numerical modelling of water subsurface reservoirs during the operation phase in underground pumped storage hydropower plants
}

\author{
Javier Menéndez ${ }^{1, *}$ and Jorge Loredo ${ }^{2}$ \\ ${ }^{1}$ HUNASER ENERGÍA, 33005 Oviedo, Spain \\ ${ }^{2}$ UNIVERSITY OF OVIEDO, Mining Exploitation Department, 33004 Oviedo, Spain
}

\begin{abstract}
Underground pumped storage hydropower (UPSH) plants may be an alternative to store subsurface energy with lower environmental impacts than conventional pumped storage hydropower (PSH) plants. Network of tunnels in closed mines (i.e. coal mines) could be used as water lower reservoir of UPSH plants. The amount of storable energy depends on the water mass and the net head between upper and lower reservoirs. Depending on the direction of the water flow rate, pumping or turbine modes may be used to produce or consume electrical energy. Filling and emptying processes during the operation stage in the underground reservoir are complicated due to the presence of two fluids (water and air) interacting inside the network of tunnels. This paper explores the underground reservoir during the operation stage considering a water flow rate of $55 \mathrm{~m}^{3} \mathrm{~s}^{-1}$. Two-phase three dimensional CFD numerical models using Ansys Fluent have been developed in order to know the behaviour of the air flow on tunnels and ventilation shaft. Static pressure and air velocity have been analyzed in the simulations at the exit of the ventilation shaft as well as the junction zone between the ventilation shaft and the tunnels network. The results obtained show that a static pressure up to $8,600 \mathrm{~Pa}$ and air velocities up to $80 \mathrm{~m} \mathrm{~s}^{-1}$ could be reached in turbine mode considering a vent shaft with $1 \mathrm{~m}$ in diameter. The static pressure increases up to 258,000 $\mathrm{Pa}$ if a ventilation shaft of $0.5 \mathrm{~m}$ in diameter is considered.
\end{abstract}

\section{Introduction}

In 2017, the share of energy from renewable sources in gross final consumption of energy, in the European Union (EU), reached $17.5 \%$, up from $17.0 \%$ in 2016 and more than double the share in $2004(8.5 \%)$, the first year for which the data are available [1]. The share of renewables in gross final consumption of energy is one of the headline indicators of the Europe 2020 strategy. The EU's target is to obtain $20 \%$ of energy in gross final consumption of energy from renewable sources by 2020 and at least $32 \%$ by 2030 [2].

The increase of variable renewable energies (VRE) in the electricity mix, such as wind or photovoltaic, energy storage systems (ESS). Pumped-storage hydropower technology (PSH) is the most mature and efficient technology that currently exists. Other systems, such as Compressed Air Energy Storage (CAES) or Suspended Weight Gravity Energy Storage (SWGES) plants, have also been analyzed as an alternative. Underground pumped storage hydropower (UPSH) could reduce the environmental impact compared to conventional PSH. UPSH plants could use disused underground space as underground water reservoirs [3-11].

The stored energy depends on the water mass $(\mathrm{kg})$ and hydraulic net head $\left(\mathrm{mH}_{2} \mathrm{O}\right)$ between upper reservoir (surface) and lower reservoir (underground). UPSH plants can work as turbine (producing electricity) or as pump (consuming electricity).

Other uses for closed mines have also been studied. Mine waters from closed and flooded mines can be used as geothermal resource for heating and cooling of buildings [12-14]. Subcritical cycle heat pumps are usually used to produce thermal energy in existing geothermal plants with mine water.

This paper explores the lower reservoir of UPSH plants during the operation phase. Three-dimensional CFD numerical models have been developed in order to know the behaviour of the underground reservoir (network of tunnels) of an UPSH plant. Filling process with a water flow rate of $55 \mathrm{~m}^{3} \mathrm{~s}^{-1}$ has been considered in turbine mode. Air velocity and static pressure in the ventilation shaft have been estimated in the simulations.

\section{Methodology}

\subsection{Schematic diagram of UPSH plants}

Fig. 1 shows a schematic diagram of the UPSH plant. A network of tunnels with $30 \mathrm{~m}^{2}$ of cross section and 200 $\mathrm{m}$ of length has been designed as lower reservoir for an UPSH plant in closed mines. Francis pump-turbine is

Corresponding author: javiermenendezr@gmail.com 
located in the powerhouse cavern with motor-generator and a ventilation shaft is also considered to expel the air during turbine operation. The penstock is located in the current vertical shaft. Finally, a surge tank has been considered to absorb sudden rises of pressure (water hammer) during the operation stage, mainly in pumping mode.

The storable energy in PSH plants depends on the water mass and net head between the upper and lower reservoir [8]. If the water mass and the net head are fixed, the output power of the Francis turbine depends on the cycle time at full load.

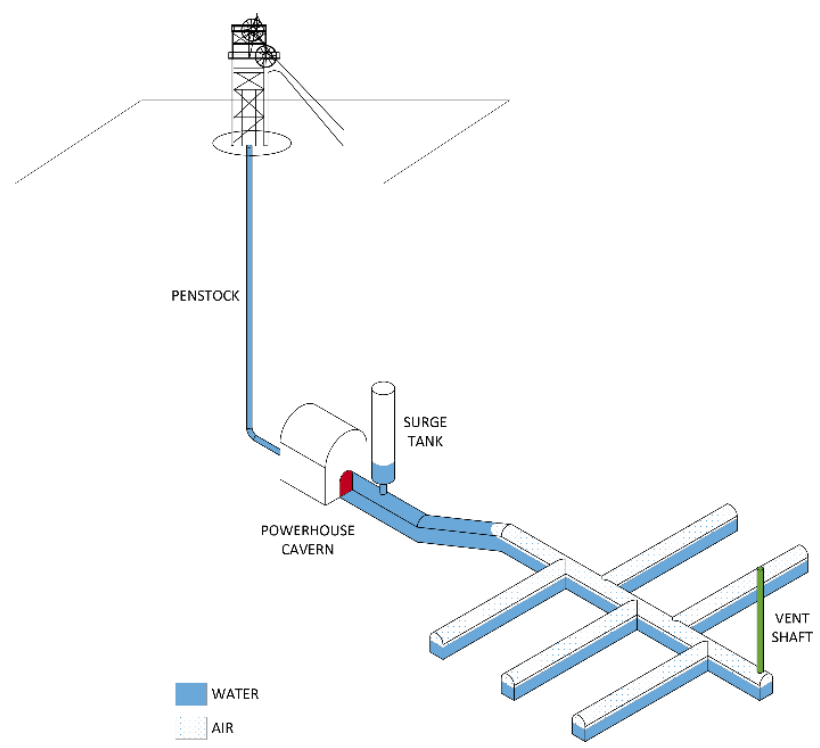

Fig. 1. CFD Three dimensional numerical model. Schematic diagram of the underground lower reservoir in abandoned mines: network of tunnels, penstock (current vertical shaft), powerhouse cavern (Francis pump-turbine and motorgenerator), surge tank and ventilation shaft.

Filling and emptying processes during the operation stage in the underground reservoir are complicated due to the presence of water and air interacting inside the network of tunnels. Fig. 2 shows a schematic diagram of air (initial stage) and water-air during the operation phase in turbine mode. The air flow comes out through the ventilation shaft during the filling process.
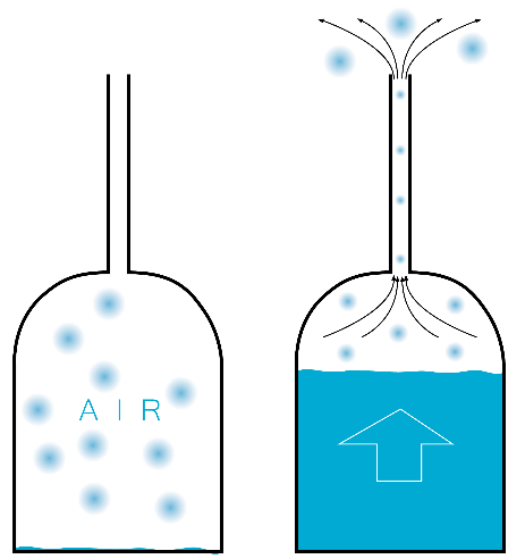

Fig. 2. Air (left) and water-air (right) flow inside the underground reservoir in turbine mode.
The effect of the air pressure during the operation stage may reduce the Francis turbine efficiency and energy production. Menendez et al. (2019) analyzed this effect and the reduction could reach up to $12 \%$ of the available energy in turbine mode [15].

\subsection{Mesh geometries, boundary conditions and numerical simulation}

The simulations were performed with the commercial CFD software Ansys Fluent V16.0, solving the NavierStokes equations. Two different model have been designed for vent shafts with $1 \mathrm{~m}$ and $0.5 \mathrm{~m}$ in diameter. A three-dimensional structured mesh has been developed for the domain. Tetrahedral and hexahedral cells have been used because of their suitable adaptation to the geometry that was considered by the $3 \mathrm{D}$ model. The mesh used for the calculations reaches up to $4.9 \cdot 10^{6}$ cells for the model with a vent shat of $1 \mathrm{~m}$ in diameter and $4.78 \cdot 10^{6}$ cells for the model with $0.5 \mathrm{~m}$ in diameter. Fig. 3 and Fig. 4 show the mesh details of the 3D model.

The Volume Of Fluid (VOF) approach has been selected for the two-phase modelling [16]. To solve the equations during the water filling process (turbine mode) of the underground reservoir, a set of boundary conditions have been selected. In the case of the air outlet in the ventilation shaft, the standard atmospheric pressure $(101,325 \mathrm{~Pa})$ was set. Furthermore, for the water inlet in the tunnels, a velocity of $1.83 \mathrm{~m} \mathrm{~s}^{-1}$ has been considered, to obtain a flow rate of $55 \mathrm{~m}^{3} \mathrm{~s}^{-1}$ at the entrance of the Francis turbine. A roughness coefficient of $3 \mathrm{~mm}$ on the shaft walls.

In the two-phase model that has been developed for the present work, air and water have been considered to have constant densities and dynamic viscosities. The values used for this parameters have been: density of $1.225 \mathrm{~kg} \mathrm{~m}^{-3}$ and a dynamic viscosity of $1.78 \cdot 10^{-5} \mathrm{~kg} \mathrm{~m}^{-1}$ $\mathrm{s}^{-1}$ for the air; and a density of $998 \mathrm{~kg} \mathrm{~m}^{-3}$ and dynamic viscosity of $1.003 \cdot 10^{-3} \mathrm{~kg} \mathrm{~m}^{-1} \mathrm{~s}^{-1}$ for the water fluid [9]. Finally, variable time stepping has been used in order to automatically change the time step when an interface is moving through dense cells or when the interface velocity (water-air) is high. The variable time step is based on the maximum Courant number near the VOF Fluid interface.

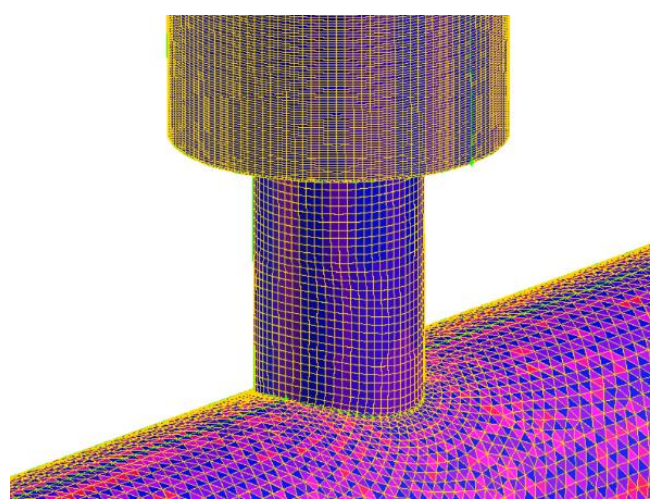

Fig. 3. Mesh details of the model. Surge tank-network of tunnels. 


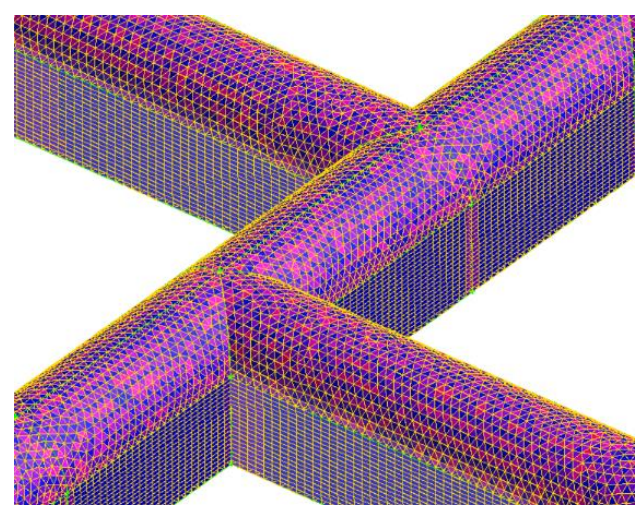

Fig. 4. Mesh details of the model. Network of tunnels.

\section{Results and discussion}

Static pressure and air velocities were tracked at the exit of the ventilation shaft. The results for the junction zone between the tunnels and the ventilation shaft have also been monitored. The simulations were performed considering ventilation shafts with $0.5 \mathrm{~m}$ and $1 \mathrm{~m}$ in diameter. The static pressure and air velocity in the shafts depends on the water flow rate and the diameter of the vent shaft. The air velocity values are the same at the exit and in the junction zone, but the static pressure is lower at the exit than in the junction zone, due to the pressure drop along the vent shaft.

Fig. 5 shows the map of results of air velocity at the exit of the ventilation shaft considering a diameter of the duct of $1 \mathrm{~m}$. The air velocity reaches up to $80 \mathrm{~m} \mathrm{~s}^{-1}$ in the central area of the section.

\section{SHAFT OUTLET - D=1 m - VELOCITY MAGNITUDE $[\mathrm{m} / \mathrm{s}]$}

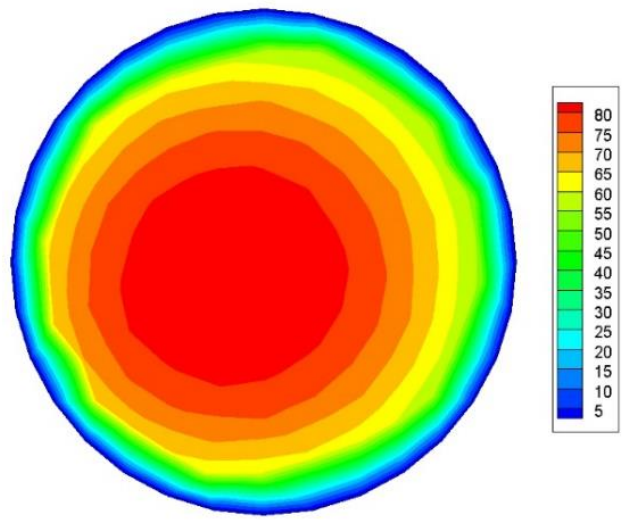

Fig. 5. Map of air velocity at shaft outlet during operation stage (turbine mode). Water flow rate of $55 \mathrm{~m}^{3} \mathrm{~s}^{-1}$ and vent shaft of 1 $\mathrm{m}$ in diameter.

Fig. 6 shows the map of results of air velocity at the exit of the ventilation shaft considering a diameter of the duct of $0.5 \mathrm{~m}$. The value of the air velocity increases up to $300 \mathrm{~m} \mathrm{~s}^{-1}$.

\section{SHAFT OUTLET - D=0.5 m - VELOCTTY MAGNITUDE $[\mathrm{m} / \mathrm{s}]$}

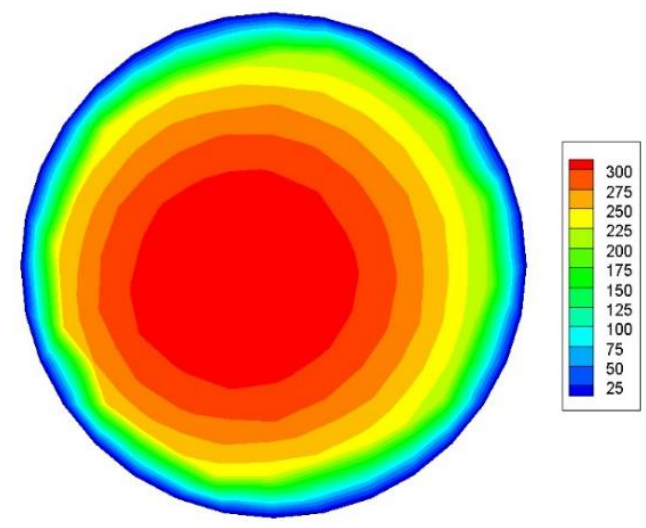

Fig. 6. Map of air velocity at shaft outlet during operation stage (turbine mode). Water flow rate of $55 \mathrm{~m}^{3} \mathrm{~s}^{-1}$ and vent shaft of $0.5 \mathrm{~m}$ in diameter.

Fig. 7 shows the map of results of static pressure at the junction zone between the tunnels and vent shaft, considering a diameter of $1 \mathrm{~m}$. The value of the static pressure reaches $8,600 \mathrm{~Pa}$. Fig. 8 shows the map of results of the static pressure considering a vent shaft of $0.5 \mathrm{~m}$ in diameter. The value of the air pressure increases up to $258,000 \mathrm{~Pa}$ (2.58 bar). At the exit of the ventilation shaft, the static pressure is reduced up to $26,000 \mathrm{~Pa}(0.25$ bar). If the design of the underground reservoir includes a ventilation shaft with 0.5 in diameter, the air pressures reached could affect to operation of the Francis turbine, and a reduction of the electricity production could be obtained.

\section{SHAFT OUTLET - D=1 m - STATIC PRESSURE [Pa]}

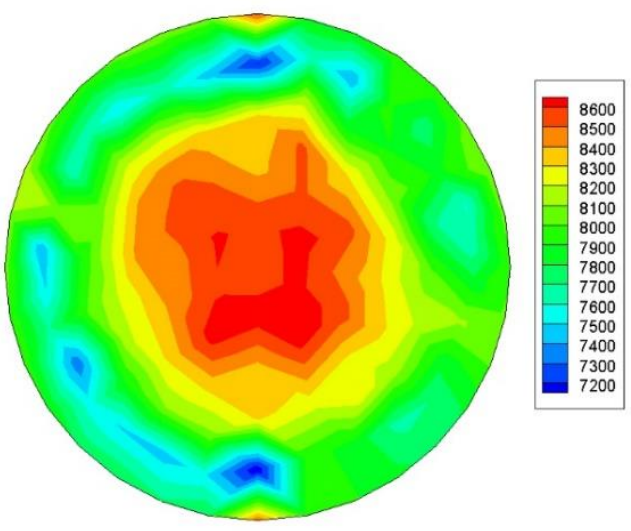

Fig. 7. Map of static pressure at the junction zone (vent shaft tunnels) during operation stage (turbine mode). Water flow rate of $55 \mathrm{~m}^{3} \mathrm{~s}^{-1}$ and vent shaft of $1 \mathrm{~m}$ in diameter. 
SHAFT-TUNNEL - D=0.5 m - STATIC PRESSURE [Pa]

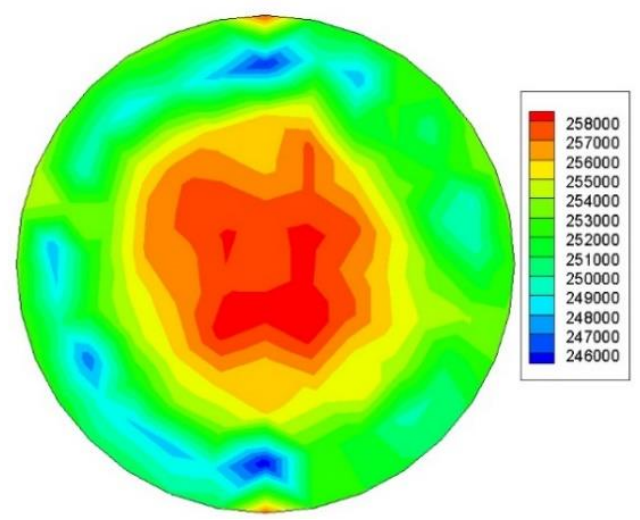

Fig. 8. Map of static pressure at the junction zone (vent shaft network of tunnels) during operation stage (turbine mode).

\section{Conclusions}

UPSH plants may be an interesting alternative to store subsurface energy. Parts of these closed mines (i.e. vertical shaft, surface area for construction of upper reservoir, etc) may be used as a lower water reservoir. Filling and emptying processes are complex due to the existence of water and air interacting.

The air flow during the operation phase could affect the operation of the Francis pump-turbine. The excavation of ventilation shafts is necessary to expel the air flow during the turbine mode.An UPSH plant with a water flow rate of $55 \mathrm{~m}^{3} \mathrm{~s}^{-1}$ requires a ventilation shaft of $1 \mathrm{~m}$ in diameter to reduce the air pressure inside the reservoir. A vent shaft of $0.5 \mathrm{~m}$ in diameter increases the air pressure up to 2.58 bar and the available energy could be reduced.

\section{References}

1. Eurostat. https://ec.europa.eu/eurostat. (Accesed 9 july 2019.

2. International Energy Agency (IEA). https://www.iea.org/. Key world energy trends, except from: renewables information.

3. Menendez J, Loredo J, Fernandez-Oro J, Galdo M. Underground pumped-storage hydropower plants with mine water in abandoned coal mines. In: Proceedings of the IMWA 13th International Congress, 2017; pp. 6-13.

4. Winde F, Kaiser F, Erasmus E. Exploring the use of deep level gold mines in South Africa for underground pumped hydroelectric energy storage schemes. Renew Sustain Energy Rev 2016;78:66882 https://dx.doi.org/10.1016/j.rser.2017.04.116.

5. Menendez J, Loredo J, Fernandez-Oro JM, Galdo M. Energy storage in underground coal mines in NW Spain: Assessment of an underground lower water reservoir and preliminary energy balance. Renew. Energy 2019; 134:1381-1391.

https://doi.org/10.1016/j.renene.2018.09.042
6. Pujades E, Orban P, Bodeux S, Archambeau P, Erpicum S, Dassargues A. Underground pumped storage hydropower plants using open pit mines: how do groundwater exchanges influence the efficiency? Appl Energy 2017;190:135-46.

https://doi.org/10.1016/j.apenergy.2016.12.093

7. Menendez J, Ordóñez A, Álvarez R, Loredo J. Energy from closed mines: Underground energy storage and geothermal applications. Renew Sustainable Energy Rev 2019;108:498-512. https://doi.org/10.1016/j.rser.2019.04.007.

8. Madlener R, Specht JM. An exploratory economic analysis of underground pumped-storage hydro power plants in abandoned coal mines. Aachen: Institute for Future Energy Consumer Needs and Behavior Working Paper No. 2/2013; 2013. Availablefrom:

https://papers.ssrn.com/sol3/papers.cfm?abstact_id= 2350106

9. Wong IH. An underground pumped storage scheme in the bukit Timah granite of Singapore. Tunn Undergr Space Technol 1996;11(4):485-9.

10. Uddin, N., Asce, M., 2003. Preliminary design of an underground reservoir for pumped storage. Geotechnical and Geological Engineering, 21: 331. Doi: 10.1023/B:GEGE.0000006058.79137.e2

11. Menendez J, Loredo J. Use of closured open pit and underground coal mines for energy generation: Application to the Asturias Central Coal Basin (Spain). E3S Web of Conferences 2019; 80: 01005. https://doi.org/10.1051/e3sconf/20198001005

12. Hall A, Scott JA, Shang H. Geothermal energy recovery from underground mines. Renew Sustainable Energy Rev 2011;15:916-24.

https://doi.org/10.1016/j.rser.2010.11.007

13. Menendez J, Ordóñez A, Fernandez-Oro JM, Loredo J, Díaz-Aguado M.B. Feasibility analysis of using mine water from abandoned coal mines in Spain for heating and cooling of buildings. Renew Energy 2020;146:1166-1176.

https://doi.org/10.1016/j.renene.2019.07.054

14. Peralta E, Breede K, Falcone G. Geothermal heat recovery from abandoned mines: a systematic review of projects implemented worldwide and a methodology for screening new projects. Environ Earth Sci 2015;73:6783-6795. https://dx.doi.org/10.1007/s12665-015-4285-y.

15. Menendez J, Fernandez-Oro JM, Galdo M, Loredo J. Pumped-storage hydropower plants with underground reservoir: Influence of air pressure on the efficiency of the Francis turbine and energy production. Renew. Energy 2019;143:1427-1438. https://doi.org/10.1016/j.renene.2019.05.099

16. Hirt C, Nichols B. Volume of fluid (VOF) method for the dynamics of free boundaries. J Comput Phys 1981;39:201-25.http://dx.doi.org/10.1016/00219991(81)90145-5 